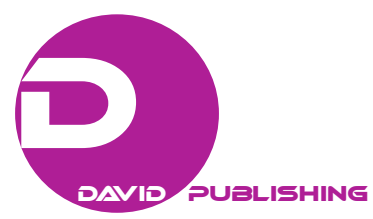

\title{
Between Two Cultures: Civil Service Reform in Thailand and Indonesia
}

\author{
Prijono Tjiptoherijanto \\ University of Indonesia, Jakarta, Indonesia
}

\begin{abstract}
In many Asian countries, public administration is in the process of considerable change and reform. Citizens in these countries have demanded faster, better, and cheaper public service. They have also demanded for more effective and efficient government. In order to meet these demands, the nation has to change its public management into more democratic, efficient, and citizen-oriented government. A civil service reform is needed in those countries with respect to their own social cultures.
\end{abstract}

Keywords: civil service reform, bureaucratic culture, political influenees, corruption

\section{Introduction}

Culture is the reflection of the economy and politics. The dominant and newly emerging forces in the economy and politics are also embedded in culture. However, culture is neither simply the ideological reflection of current forces nor the contra distinctions in the economy and politics. It is also the accumulation of notions, customs, habits, and the like which dates back to prehistory, and persists in current circumstances as long as there are transmitters and they are part of the social and psychological make-up of people within local sites.

The bureaucracy has a structure that breeds its own administrative culture. Incoming political leadership often reacts to the bureaucracy it inherits by instituting personnel purges or reorganizing or both, either to cleanse the old system and reorient it to the needs of the new dispensation, or to reshape the administrative culture and values in facilitating targeted policy and program objectives. Consequently, a new political order carries its own political culture to the regime-bureaucracy relation. As the bureaucracy accommodates and eventually trusts the new regime, an administrative culture supportive of the political leadership ensues.

\section{Public Service Reform}

In 1991, the World Bank released a report entitled "The Reform of Public Sector Management: Lesson From Experience"1 which was drawn from the experience of the World Bank and its member countries in the 1980's and has approached civil service reform from two complementary perspectives which are: short-term cost-containment measures aimed at reforming public pay and employment systems and medium-term programs

Prijono Tjiptoherijanto, Ph.D., professor of Economics, University of Indonesia, Jakarta, Indonesia.

Coresspondence concerning this article should be addressed to Prijono Tjiptoherijanto, Komplek Dosen UI No. 60, Ciputat, Tangerang Selatan 15419, Indonesia

${ }^{1}$ World Bank, Country Economic Department, “The Reform of Public Sector Management: Lesson From Experiences”, World Bank: Washington D.C., 1991. 
to build institutional support for cost-containment and to strengthen the government's ability to manage the civil service. For a short-term measure, the government pay and employment reform has focused on four main problems, such as:

(1) Excessive public sector wage bills, measured both by the ratio of personnel expenditures to government revenues or total expenditures and by the degree to which were personnel recurrent expenditures are crowded out by wages;

(2) Surplus ${ }^{2}$ civil service staff, with "surplus" defined by a range of measures and rates, including the member of civil servants in relation to the member of participants in the modern sector labor forces, and by operating budgets too low to support the current member of employees;

(3) Salary erosion, that is declines in wages that reflect not only the high level of inflation in many countries but also trade-off between expanded employment and lower average pay, and the proliferation of non-wage benefits to mitigate the fall in real pay;

(4) Wage compression, meaning low ratios between the highest and lowest civil servant salaries making it difficult to attract and retain qualified staff.

These reforms were the reaffirmation to the issue of the modernization in public service experienced by the western countries, especially in the Organization for Economic Cooperation and Development (Organization for Economic Cooperation and Development, 1990; 1993). The following factors helped to push this modernization: Firstly, it is the economic and financial pressures facing the government of such countries in the last quarter of the twentieth century and the early years of the twenty-first century. These pressures led government to question the benefits of traditional large-scale public bureaucracies and reinforced demands for greater efficiency and value of money in the operations of civil services. Governments have "reassessed their bureaucracies and demanded changes” (Hughes, 1998, p. 4).

Secondly, it is the public pressure on governments to deliver services that are more responsive to public. There has been a growing recognition that the consumer of public services should be at the heart of the arrangements for services delivery. Whereas the traditional public administration perspective was based on the idea that public sector management was different from business management, there is now a view that public administration "has everything to learn from the private sector" (Gunn, 1998, p. 21). There is a belief that "better management" can solve a range of economic and social problem faced by governments (Pollitt, 1993, p. 1) and that management techniques from the private sector should be imported into the civil service and other parts of the public service.

Thirdly, it is the growing awareness of the potential of information technology in helping to improve the efficiency and effectiveness of public service operations (Organization for Economic Cooperation and Development, 1990). Technological developments have transformed the processes of public administration. The development of information technology in the delivery of public services is one of the four administrative "megatrends" linked with the emergence of the so-called New Public Management or well known as the NPM (Hood, 1991, p. 3).

\footnotetext{
2 The nation of "surplus" contains an element of subjectivity; rigorous measures of the concept have proved difficult to devise and apply. Criteria used include comparative (cross-national) ratios of the number of civil servants to the overall population, or as percentage of the country's modern sector labor force. Another measure often used is the extent to which personnel costs “crowd out" operating budget for supplies and maintenance. In trying to determine when staff are in surplus, functional reviews and staff inspections may be undertaken to identity sector-or function-specific excess through the use of ratio analysis-which applies standardized norms of, say, proportion of agricultural extension workers to farmers.
} 
Lastly, the desire to improve political control of central government bureaucracies is another important factor in helping to explain the modernization agenda. In a number of western liberal democratic countries, the higher civil service has been seen as an abstract to control by elected politicians. Concerned that permanent officials had become too powerful in the formulation of public policy, the political leaders of many western countries have attempted "to reassert political control over the bureaucratic machine" (Pollitt \& Bouckaert, 2000, p. 155).

The public service reform is often done with respect to social and culture aspects which are observed in countries implementing the reforms. Experiences from Thailand and Indonesia are given in the following discussions.

\section{Thailand: Norms and Values}

In Thailand, the new bureaucratic culture was introduced by King Chulalongkorn who understood the demand of his time, opening the way for administrative reforms, systematic modernization, and absolute royal control. From this time onwards, Bangkok’s appointed bureaucracy was instituted, control over the Buddhist Monkhood (Sangha) established, general education introduced, and a modern communicators network built up. In the process, the corves system was abandoned and the slaves emancipated (Prizzia, 1986). However, official political culture is preoccupied with teaching morality. If everyone knows manners and behavioral conduct, the external world consisting of the wider society will be in good order. In bureaucratic manner, responsibility is specified in within six categories of duties, namely the obligations to oneself, to the family, to the school class and fellows, to the school, to the community, and to the nation-state. There are then specified in sets of six rules to follow. For example, the duties to the nation-state are: (1) to respect the law, (2) to pay taxes, (3) to assist the officials in maintaining national stability, (4) to be loyal to defending the Nation Religion-King, (5) to preserve national independence, Thai arts, and culture, and (6) to let the good of the nation prevail over self-interest (Bunsong, 1991).

The Thai bureaucracy is highly institutionalized with well-established norms and values and designated bureaucratic behavior. Human relationships in the bureaucracy are based upon certain established patterns. Then, a bureaucrat's advancement in the system tends to depend largely on the favoritism; the art of currying flavor with one's boss has been developed over the years. When a person is promoted rather rapidly in the bureaucracy, the term normally heard is "liakeng”, which literally means "good at licking”, a Thai analogy to a domestic pet which learns how to please its master by licking (sucking up) ${ }^{3}$. A generous comment would be "khao chao khao nai kent" (he knows how to smoothly approach his lord and master). Therefore, there is a general impression that the Thai bureaucratic system is plagued with personalized or patron clientelism. Even though it might not be completely true, a study of the attitude of a group of 300 public officials who underwent a training course at the National Institute of Development Administration (NIDA) in 1977 supported the fact (Nakata, 1977). From the study, 95\% of the respondents believed that professional advancement in the bureaucracy depends on a patron-client relationship; $82.7 \%$ believed that it depends on money, and $93 \%$ on knowledge and ability.

Aside from the self-contradictory result, because almost the same group of respondents' believed that professional advancement in the bureaucracy depends on the patron-client relationship (95\%) and knowledge

\footnotetext{
3 This kind of a so-called "bureaucratic culture" is also similar to the Indonesia's Civil Services which practiced "Asal Bapak Senang (ABS)" means “as the boss wishes”.
} 
and ability (93\%), it showed that these two factors were the most important factors in explaining the professional advancement in the Thai's bureaucracy. In essence, this is a combination of favouritism and merits system. This is a wary characteristic. Favouratism should not be viewed as one-way system. It is a patron-client system of: "You scratch my back and I scratch yours" (Nakata, 1977, pp. 26-36), which involves three levels of relationships-for superiors, subordinates, and equals. As one writer put it:

Working in bureaucracy, you must try to gain experience, to understand human relations and to be able to catch up with all the tricks. You cannot just depend on work efficiency but you must also use your knowledge to understand the nature of environment. That is to be able to succeed in a bureaucracy, you must be pulled by your superiors, pushed by your subordinates and supported by your equals (Pooyai dueng, poonoidun. Kou samaeokan sanubsanoon) ${ }^{4}$.

Therefore, the art of gaining favor inside the bureaucratic cukture is not an easy task. It involves a number of people, techniques, and sacrifices in terms of one's principle and self-respect.

Another feature of the Thai's bureaucracy is the significant role of the bureaucrats in the administration and politics. These career bureaucrats, especially those in the top echelon, have virtually monopolized political and administrative power, running the routines as well as initiating policy. Thus, the bureaucrats assume administrative as well as political power. Therefore, the feature of the bureaucracy in Thailand can also be described as a "bureaucratic polity" (Riggs, 1966) 5 .

The concept of the bureaucratic polity referred both to a particular type of political regime and also to the influence of Thai bureaucratic culture on the mode of governance. Military rules frequently ousted elected governments in Thailand and substituted their own form of rule, copting civilian elements as they saw it. The power of bureaucrats stemmed in large part from the reliance of the military on the bureaucrats elite in order to rule effectively. Thus, the bureaucratic polity was one in which bureaucrats were permanent member of the political class. Chai-anan (1987) provided as typical analysis of Thai bureaucratic culture: The bureaucracy was hierarchical by organized in order to reflect differential status and power consideration rather than a national division of labor or chain of command; it gave priority to personnel relations of patron age and dependency, with deference and loyality being more important than merit, and it emphasized above all else security for its members.

Thai bureaucracy was typified by corruption, facturalism, departementalism, and a tendency to diffuse esponsibility for making decisions so as to preserve the status and autonomy of individuals, cliques, and departments (Siffin, 1966). Purchase of office was common in the senior ranks (Ockey, 2004). "Money politics" dominated the electorial and parliamentary processes. However, the bureaucracy retained a considerable degree of control over polity as well as administration, because coalition governments were generally weak and indecisive (Bidhya, 2001).

In sum, functional nationality was not the main organizing principle of Thai bureaucratic norms and practices. Nevertheless, there were some parts of the state machinery that developed a reputation for technocratic excellence, such as the National Economic and Social Development Board (NESDB), the Bureau of the Budget (BOB), Office of the Civil Service Commission (OCSC), and the Bank of Thailand (BOT). But

\footnotetext{
${ }^{4}$ Kroo Ha (Pseudonym), “Cha Pen Huana (To Be a Boss)” in Warasarn Rachakasn (Civil Service Journal) Vol. IX, No. 2 (B.E. 2507), pp. 21-23.

5 The term "bureaucratic polity" was developed by Fred Riggs to describe his model for understanding the Thai political system as he found in the 1905 .
} 
even there islands apparent technocrat of reforming zeal were something of mirage ${ }^{6}$. The influence of political on the bureaucratic culture is still significant. “...Because top official wanted to please politicians in order to keep their position secure” (Nukul Commission Report, 1988, pp. 169-172).

\section{Indonesia: Morality and Corruption}

In countries, such as Indonesia where civil servants like politicians are key government decision makers, government employees are sometimes viewed as community leaders. In this sense, civil servants may be expected to perform many duties in the community where they live, following practices established during the Dutch colonial era. Such role calls for adherences to norms and morality meaning the civil servants must avoid irregularities and always obey the rules when conducting their activities (Magnis, 1996; Natakusumah, 1990). Therefore, civil servants should not engage in illegal activities, such as bribery, corruption, and other misconducts.

Friederich (1940) noted growing importance of internal values and moral and professional standards among bureaucrats. In their absence, abuse of power can easily arise in the government sector.

A study by Meier and O'Toole (2006) showed that bureaucratic values are far more important in explaining bureaucratic output and outcomes than political factors. This should be taken to mean that external political control is unimportant, but it does show that paying serious attention to the values of civil servants is important.

Ensuring that civil servants give high priority to honesty, responsibility, and integrity with regard to their routine duties can be accomplished through well-planned human resource development. Human resource development for civil servants starts with their recruitment and continues until they leave government service. Recruits should undertake job and requirement analyses before undertaking recruitment activities. Furthermore, to allow the civil service to select the best candidates, the recruitment process should be fair and open.

The next step in human resource development for civil servants is education and training. This should be provided regularly for those at every level, as is already done in the armed forces. Considering the importance of trainings in Indonesia training and education plays a major role in the effort to increase the quality of civil service. However, training and education (pendidikan dan pelatihan-diklat) aims not only at the improvement of job- and work-related skills and knowledge. Forming the attitudinal and behavioral characteristics of civil servants and ensuring their political allegiance with the programe of the government have always been an integral part of the human resources development programes of the government.

To complement public sector reform in improving transparent and accountable governance, Indonesia implemented a series of measures designed to combat corruption during the reformation period. The Corruption Eradication Commission (KPK) was formed in 2003, five years after the fall of the Suharto's government, to coordinate and supervise anti-corruption efforts, while focusing on eliminating and preventing corruption and conducting a system review. It undertakes this mission on the assumption that a comprehensive, systematic, and long-term approach is needed to achieve a "corruption-free Indonesia”, which must by definition include the holistic participation of all stakeholders. As such, its aim is to become a driver of change in cultivating a culture of anti-corruption in Indonesian society, government, and the business world (Sunaryadi, 2007).

\footnotetext{
${ }^{6}$ From discussion with the faculty members of the Faculty of Economics, Thamasat University, Bangkok, Tuesday, March 25, 2008.
} 
The KPK is independent from the executive, legislative, and judicial branches and responsible to the general public. It receives funding from the state budget and donors. Its activities include coordination, supervision, investigation, prosecution, prevention, and system review. In terms of staff, it has five commissioners, two advisors, and 600 staff members. These human resources face a population of over 230 million people, around four million of whom are public servants, within the many provincial and local governments.

The KPK's duties include supervision and coordination of institutions authorized to eradicate corruption; investigation, indictment, and prosecution of corrupt acts; preventive actions against corrupt acts; monitoring state governance and prosecutions against criminal acts of corruption; implementing a reporting system for the purposes of eradicating corruption, requesting information from relevant institutions for the purposes of eradicating corruption; arranging opinion hearings and meetings with institutions authorized to eradicate corruption; and requesting for reports from relevant institutions pertaining to the prevention of criminal acts of corruption. Law No. 30 of 2002 on the Corruption Eradication Commission provided the basis for the functions, authority, and duties of the institution.

One initial challenge in the fight against corruption related to the way in which it was defined. Over the 1971-2004 period, laws and regulations tended to address only those types of corruption that represented a direct loss to the state apparatus. As of 2006, a publication called "Memahami Untuk Membasmi” now identifies 30 distinct types of corruption, many of which were previously overlooked. In addition to defining two types of corruption representing a loss to the state, other major categories of corruption include 12 types of bribery, five types of embezzlement, six types of procurement fraud, one type of procurement conflicts of interest.

The KPK also faced other other challenges. Its establishment followed a long history of anti-corruption measures, most of which had focused primarily on investigation of existing cases of corruption, rather than on prevention (see Table 1). As a result of this lack of emphasis on prevention, many of the lessons learned from early efforts were not applied on an ongoing basis. Consequently, Indonesia found that the same kinds of corruption were equally prevalent over the course of decades. For example, people at similarly high level positions were arrested for comparable offences in the 1950s, 1970s, 1980s, and again in the 2000s. Similarly, the same types of procurement corruption happened in 1983 and 2003. Areas perceived as highly corrupt in the 1970s continued to give the same impressions.

Table 1

History of Key Anti-corruption Measures in Indonesia, 1957-2007

\begin{tabular}{ll}
\hline 1957 & Order to fight corruption (Military Commander) \\
\hline 1967 & Presidential Decree to fight corruption through prevention and repression (Corruption Eradication Team) \\
\hline 1970 & Presidential Decree to access corruption and its solution (Commission of Four) \\
\hline 1977 & Presidential instruction to take disciplinary action in operations and administration (Disciplinary Team) \\
\hline 1997 & Ministry of Finance order for a special operation on corruption in taxation (Special Re-audit on Tax Return) \\
\hline 1999 & Asset examination and disclosure law for public officials (Public Official Wealth Examiner) \\
\hline 2003 & Government regulations to investigate complex corruption (Corruption Eradication Joint Team) \\
\hline $2005-2007$ & KPK established
\end{tabular}

Source: Author's compilation from various sources. 
To address this situation, the KPK has aimed to use an integrated programme implementation approach, which includes capacity development, prevention, repression of corruption, and public involvement and participation. This entailed a shift in focus for programmes to combat corruption. The KPK placed attention on the issue of bribery, catching "big fishes", winning public trust, using court video recordings, bureaucratic reform, and integrating investigation and prevention measures. These polices have resulted in many highly publicized cases where senior officials were caught "red-handed" on videotape in the process of conducting an illegal act. At the same time, court video recording helped to increase transparency and public awareness of court procedures and decisions. Between 2007 and 2010, significant anti-corruption reforms were completed to increase legal certainty, reduce budget leakages, increase investment, and increase state revenues. The ongoing commitment to anti-corruption is expected to gradually increase citizen trust in government, while additionally improving investor confidence.

\section{Final Remarks}

Civil service reform as parts of the bureaucratic reform should be designed to reduce corruption. If officials are paid much less than those with similar training elsewhere in the economy, only those willing to accept bribes will be attracted to the public sector. The rest will work in private enterprises. But in spite of the low pay, positions in the state bureaucracy can be valuable assets. In some developing countries, there is a lively market for bureaucratic positions that generate large bribes. Positions in corrupt police departments are likely to be especially valuable (Phongpaicit \& Piriyangsaran, 1996). Civil service wages should be set equivalent to the wages of those in similar positions within the private sector so as to enable service without corruption and misconducts.

Bureaucratic reform is expensive and politically difficult, and it may seem beyond the capacity of many poor countries. Yet it cannot be avoided in any credible reform effort. Therefore, structural and administrative reforms which have been introduced in most developing countries should be directed to free the civil service from politics and the civil servants from political pressure. This is the primary reason for the merit-based civil service reforms in which entry into the service is qualification-based determined, among others, competitive examinations and promotions to higher positions are based on performance, competence, and other merit-based standards and not on connections.

\section{References}

Bidhya, B. (2001). Thailand: Bureaucracy under coalition governments. In J. P. Burns and B. Bidhya (Eds.), Civil service systems in Asia. Cheltenham, UK: Edward Elgar Publishing Ltd.

Bunsong, C. (1991). Ethics, Book 5 (in Thai). Bangkok, Thailand: Watthana Phanit.

Chai-anan, S. (1987). Rat (the state). Bangkok, Thailand: Chulalongkorn University.

Friederich, C. J. (1940). Public policy and the nature of administration responsibility. In C. J. Friederich and E. S. Mason (Eds.), Public policy (pp. 3-24). Cambridge, MA: Harvard University Press.

Gunn, L. A. (1998). Public management: A third approach. Public Money and Management, 8(1-2), 21-26.

Hood, C. (1991). A public management for all seasons. Public Administration, 69(1), 3-19.

Hughes, O. E. (1998). Public management and administration: An introduction (2nd ed.). London, UK: McMillan.

Magnis, S. F. (1996). Morality in bureaucracy (in Bahasa Indonesia). Paper presented at The Meeting on The Efficiency and Effectiveness of Bureaucratic Work Patterns and the Quality of Nine Years of Elementary Education in Relation to the Era of Globalization: Especially in 2003 and Beyond, Jakarta.

Meier, K. J., \& O’Toole, L. J. Jr. (2006). Political control versus bureaucratic values: Reframing the debate. Public Administration Review, 66(2), 177-192. 
Nakata, T. (1977). Bureaucratic corruption in Thailand: Incongruities between legal codes and social norms (Monograph in Public Administration, School of Public Administration, Bangkok, Thailand).

Natakusumah, P. (1990). Quality improvement of government employee (in Indonesian). Jakarta: National Institute of Administration (LAN).

Nukul Commision Report. (1998). Analysis and evaluation of facts behind Thailand's economic crisis. Bangkok, Thailand: The NATION.

Ockey, J. (2004). State, bureaucracy and polity in modern Thai politics. Journal of Contemporary Asia, 34(2), 143-162.

Organization for Economic Cooperation and Development. (1990; 1993). Public management development: Survey 1990 and Survey 1993. Paris, France: OECD.

Phongpaicit, P., \& Piriyangsaran, S. (1996). Corruption and democracy in Thailand. Chiang Mai, Thailand: Silkworm Books.

Pollitt, C. (1993). Managerialism and the public services: Cuts or cultural change in the 1990's (2nd ed.). Oxford, UK: Blackwell.

Pollitt, C., \& Bouckaert, G. (2000). Public management reform: A comparative analysis. Oxford, UK: Oxford University Press.

Prizzia, R. (1986). King Chulalongkorn and the reorganization of Thailand's provincial administration. In R. D. Renard (Ed.), A memoriam Walter Vella. Honolulu, USA: University of Hawaii.

Riggs, F. W. (1966). Thailand: The modernization of a bureaucratic polity. Honolulu, USA: East West Center Press.

Siffin, W. J. (1966). The Thai bureaucracy: Institutional change and development. Honolulu, USA: East West Center Press.

Sunaryadi, A. (2007). Indonesia experiences: Programmes to combat corruption. Context Presentation at The Regional Forum on Reinventing Government in Asia, Jakarta.

World Bank, Country Economic Development. (1991). The reform of public sector management: Lesson from experiences. Washington DC, USA: World Bank. 